\title{
ТЕХНОЛОГІЯ ЛІКАРСЬКИХ ЗАСОБІВ ПРОМИСЛОВОГО ВИРОБНИЦТВА ЯК ДИСЦИПЛІНА В СИСТЕМІ ПІДГОТОВКИ ПРОВІЗОРА-КОСМЕТОЛОГА
}

М. М. Васенда

ДВНЗ “Тернопільський державниймедичний університет імені І. Я. Горбачевського МОЗ України”

\section{TECHNOLOGY OF INDUSTRIAL DRUGS AS A DISCIPLINE IN THE TRAINING SYSTEM OF A PHARMACISTS - BEAUTICIANS}

\author{
M. M. Vasenda
}

SHEI "Ternopil State Medical University by I. Ya. Horbachevsky of MPH of Ukraine"

\begin{abstract}
Викладено основні методичні підходи до викладання дисципліни “Технологія лікарських засобів промислового виробництва” студентам фармацевтичного факультету, спеціальності “Технологія парфумерно-косметичних засобів”.

Basic methodical approaches of teaching the course "Technology of industrial drugs" are presented for students of the Pharmaceutical Faculty specialty "Technology of perfumery and cosmetics products".
\end{abstract}

Вступ. Виробництво вітчизняних лікарських та парфумерно-косметичних засобів належить до найбільш пріоритетних і соціально значущих напрямків розвитку та перебудови економіки України. В останні роки вітчизняний ринок лікувальної та декоративної косметики стрімко розвивається.

Лікувальну косметику можна придбати в аптеках та отримати кваліфіковану консультацію фахівцівпровізорів та допомогу в обгрунтованому виборі лікувальних косметичних засобів [1]. На жаль, обсяги виробництва даних засобів в умовах аптек незначні, але їх важко підробити [2-4].

На сьогодні в Україні майже 90 \% ринку лікувальної косметики обіймають іноземні фірми, а вітчизняні виробники - лише $10 \%$ [1]. Для розвитку вітчизняної індустрії лікувальної та декоративної косметики необхідна фахова підготовка спеціалістів.

Недостатня кількість підготовлених кадрів для всіх сфер діяльності, самеу вітчизняній парфумерно-косметичній галузі на сьогодні $є$ досить актуальною проблемою. Тому на базі фармацевтичних спеціальностей було відкрито нову спеціальність "Технологія парфумерно-косметичних засобів”. Дана спеціальність дозволяє випусникам працювати не тільки в косметичних салонах та клініках, але і на підприємствах з виробництва парфумерно-косметичної продукції, лабораторіях з контролю якості парфумернокосметичних виробів.
У 2003 р. Тернопільський державний медичний університет також розпочав підготовку фахівців за спеціальністю "Технологія парфумерно-косметичних засобів" з кваліфікацією "Провізор-косметолог”. У 2008 році спеціальність пройшла акредитацію Державної акредитаційної комісії Міністерства освіти і науки України і отримано право на підготовку фахівців освітньо-кваліфікаційного рівня “Спеціаліст".

Підготовку спеціалістів зі спеціальності “Технологія парфумерно-косметичних засобів" здійснюються як кафедрами фармацевтичного, так і медичного факультетів, за сучасними навчальними планами з використанням новітніх методик, урахуванням зарубіжного досвіду і потреб сучасності, враховуючи специфіку майбутньої професійної діяльності. У процесі практичної підготовки майбутні спеціалісти мають змогу під керівництвом досвічених фахівців розробляти нові засоби лікувальної косметики, схеми догляду за шкірою, проводити різноманітні косметичні процедури та інше.

Основна частина. Однією із профілюючих дисциплін є “Технологія лікарських препаратів промислового виробництва” [5], яка вивчається згідно з типовою робочою програмою [6] на IV курсі. Згідно 3 кредитно-модульною системою на предмет виділено 162 год / 4,5 кредиту.

Для освоєння матеріалу виділено 20 годин лекцій, 70 год практичних занять та 72 год СПРС. У кінці семестру передбачено семестровий тестовий контроль.

(C) М. М. Васенда 
Метою вивчення дисципліни “Технологія лікарських препаратів промислового виробництва" $є$ формування у студентів теоретичних знань та практичних навичок з методів підготовки, обробки, виробництва, транспортування, зберігання лікарських препаратів (матеріалів, напівпродуктів, готових продуктів) та контролю їх якості. Детальне і грунтовне ознайомлення з основами виробництва лікарських засобів дає можливість більш повно засвоїти матеріал, що вивчається, реалізувати науково-творчий потенціал студента, збагачує його знаннями, які безпосередньо будуть використані в практичній діяльності.

Вивчення дисципліни розбито на два змістових модулі, що включають основні теми даного предмета: теоретичні основи екстрагування, виробницво екстракційних препаратів, обладнання для екстрагування, згушування та висушування витяжок, технологія твердих лікарських засобів, особливості виготовлення таблеток, желатинових капсул, стерильне виробництво та технологія мазей, супозиторіїв та пластирів.

Також передбачено проходження навчальної практики з даної дисципліни в кінці весняного семестру, що дозволить закріпити, поглиблити та розширити теоретичні знання, отримані під час вивчення дисципліни, ознайомитися із структурою, особливостями фармацевтичних підприємств, особливостями технологічних процесів лікарських засобів, будовою та роботою основного технологічного устаткування. Студенти мають можливість наочно ознайомитися з виробництвом лікарських засобів та пройти практику на базі фармацевтичного підприємства “Тернофарм”.

При вивченні даної дисципліни студентам читаються лекції з мультимедійним супроводом. Обов'язковим при вивченні “Технологіїлікарських засобів промислового виробництва" $є$ відеофільми про технологічні аспекти виготовлення тієї чи іншої лікарської форми, що дозволяє студентам краще сприймати нову інформацію. На лекцію студент приходить підготовленим, оскільки з лекційним матеріалом він має змогу ознайомитися на Web-порталі університету. Це, звичайно, підвищує рівень засвоєння прочитанного матеріалу. Оскільки вітчизняне виробництво лікарських засобів стрімко розвивається, оновлюється, тому викладачам необхідно весь час вдосконалювати лекційний матеріал відповідно до сучасних тенденцій у світовій фармації.

Практичні заняття з даної дисципліни проводяться згідно з методикою “єдиного дня”, відповідно до якої навчання для студентів становить 5 робочих днів, 3 них 1 день - лекційний та 4 дні-практичні заняття.
На практичних заняттях студенти 3 "Технології лікарських засобів промислового виробництва” складають технологічні схеми виробництва лікарських засобів, матеріальні баланси, згідно з якими готують лікарські форми. Для кращого засвоєння матеріалу студентам на семінарській частині практичного заняття пропонуються різні ситуаційні задачі, де необхідно швидко прийняти правильне рішення, щодо покращення технологічних аспектів виготовлення лікарських перапарів, при цьому необхідно застосувати знання не тільки з даного предмета, але із інших фармацевтичних дисциплін. Для узагальнення знань у кінці практичного заняття проводиться письмовий тестовий контроль.

Для якісноговивчення дисципліни розробленінавчальні таблиці, є доступ до мережі Інтернет, що дозволяє студентам розширювати та поглиблювати свої знання.

Для полегшення орієнтування студентів в індивідуальній навчальній програмі web-портал університету в розділі "Інтранет / студентські орієнтири /на допомогу студентам" наповнений робочими програмами, розкладом лекцій та практичних занять, презентаціями лекцій, матеріалами підготовки студентів до лекцій та практичних занять, а також методичними вказівками. Всі матеріали розміщені у форматі $\mathrm{html}$, що дозволяє студентам обробляти запропоновані матеріали на персональних комп'ютерах. Дана інформація дублюється і в системі Moodle.2,0.

Для перевірки своїх знань 3 вивченої теми в системі Moodle.2,0 створено тестову базу даних, що дозволяє кожному студенту в домашніх умовах оцінити знання з вивченого матеріалу напередодні практичного заняття. При отриманні негативної оцінки студент може їі покращити на занятті.

У кінці семестру студенти складають тестовий іспит з "Технології лікарських засобів промислового виробництва". Для підготовки до іспиту студентам надаються консультації, а також на сайті університету подаються тестові завдання, які крім тестових питань вміщують і тестові питання до рисунків, що наведені у “Збірнику рисунків для підготовки до семестрового тестового іспиту”.

Позитивне значення у виченні предмета має опанування практичними навичками, що контролюється складанням, після вивчення дисципліни, об' єктивного структурованого практичного іспиту (ОСПІ) та проведенням навчальної практики на фармацевтичному підприємстві.

Для розвитку творчих навичок та розвитку науково-дослідної роботи студенти залучаються до наукового гуртка, що діс на кафедрі. Студенти досить 
активні, працьовиті, беруть участь у різноманітних наукових конференціях, конгресах. Ті знання, які вони отримують на базі фармацевтичного факультету, дозволять їм повніше проявити себе у майбутньому чи як провізор-косметолог, чи як технолог на вітчизняних підприємствах.

\section{Література}

1. Ольховська А. Б. Маркетингові дослідження вітчизняного ринку лікувальної косметики / А. Б. Ольховська, М. М. Кобець, Л. С. Фелоненко // Управління, економіка та забезпечення якості в фармації. - 2011. - № 3. - С. 63-68.

2. Гладько В. В. Средства ухода за кожей в аптечном ассортименте / В. В. Гладько, С. А. Масюкова, Л. В. Некрасова // Новая аптека.-2006.-№ 3.- С. 24-30.

3. Лоскутова Е. Е. Стратегическая оценка рынка лечебной косметики / Е. Е. Лоскугова, Е. В. Турубара, И. В. Косова // Ремедиум. - 2007. - № 11. - С. 21-24.

4. Walker O. Marketing strategy: Planning and implementation / O. Walker, C. Larreche. - [2ed.]. - Boston :
Висновок. Для підготовки студентів спеціальності “Технологія парфумерно-косметичних засобів” важливе місцезаймає вивчення дисципліни “Технологія лікарських засобів промислового виробництва”, оскільки дозволяє студентам систематизувати знання та використовувати їх у професійній діяльності.

Irwin: McGraw Hill, 1996. - 392 p.

5. Технологія лікарських препаратів промислового виробництва Навчальний посібник / [Д. І. Дмитрієвський, Л. І. Богуславська, Л. М. Хохлов та ін.]; за ред. Д. І. Дмитрієвського. - [2-ге вид.]-Вінниця : НОВА КНИГА, 2008. - 280 с.

6. Технологія лікарських препаратів промислового виробництва. Типова програма навчальної дисципліни для студентів вищих фармацевтичних навчальних закладів та фармацевтичних факультетів вищих медичних навчальних закладів III-IV рівнів акредитації. Спеціальність: 7.110202 "Технологія парфумерно-косметичних засобів". - Київ, 2012. 